\title{
Observaciones gramaticales en el comentario de Abraham Ibn Ezra a Lamentaciones
}

\author{
M. ${ }^{a}$ Teresa Ortega-Monasterio * \\ Instituto de Filología - CSIC, Madrid
}

\begin{abstract}
Abraham Ibn Ezra es uno de los comentaristas españoles medievales que más nos ilustran sobre el texto bíblico. Como es bien sabido, en sus comentarios se tratan temas de prácticamente todas las ciencias del momento -astrología, astronomía, o filosofía-, y en todos ellos se refiere a temas gramaticales. Le preocupa enormemente la lengua hebrea, su evolución, su sintaxis y su morfología, como ya hemos visto en numerosos trabajos publicados sobre ello.
\end{abstract}

En esta ocasión, analizaré las cuestiones gramaticales que aparecen en su comentario a Lamentaciones. Ibn Ezra lo escribe dividiéndolo en dos partes, y hace dos comentarios a cada capítulo del libro: el comentario gramatical, en primer lugar, y el que llama Peruš ha$T e^{3}$ amîm, en segundo lugar, excepto en el capítulo quinto, donde solamente existe el primero. Ya en la introducción explica que va a hacer su comentario «según la gramática». Dice literalmente Ibn Ezra: וכן אפרש זאת המגלה אחרי הדקדוקים. Con estas palabras indica que, a su juicio, el comentario que más le importa es el gramatical,

${ }^{*}$ monasterio@filol.csic.es.

Sefarad 63 (2003) págs. 371-391

(1) CSIC

ISSN 037-0894 
por lo menos en este libro. Utiliza la palabra דקדוק para designar la gramática en el sentido más amplio, y en contraposición a טעם, con el que designa el sentido de las palabras ${ }^{1}$. Por eso distingue claramente en cada capítulo de Lamentaciones los dos comentarios. El estilo de ambos coinciden. Se trata del típico estilo del pešat, de extrema concisión, característico de nuestro autor. En el primero de ellos, hace frecuentes alusiones a notas gramaticales: más bien se trata solamente de notas gramaticales, entremezcladas con aclaraciones sobre el significado de las palabras, ya que también le preocupa enormemente que el lector entienda perfectamente el sentido del texto de la Biblia. La exégesis de Ibn Ezra se basa en una interpretación esencialmente filológica, donde se armoniza esta interpretación con el texto bíblico y con el razonamiento. Con ello, intenta aclarar los pasajes oscuros de la Biblia. A continuación, veremos alguna de estas notas gramaticales del comentario a Lamentaciones, comparándolas ocasionalmente con las de otros comentaristas medievales anteriores.

\section{EXPRESIONES}

En el comentario existen numerosas expresiones que, con frecuencia, también aparecen en otros comentarios del autor. Por ejemplo, para dar opiniones de otros autores, raramente se refiere a ellos por su nombre: utiliza la expresión יש אומרים, añadiendo antes o al final su parecer, introducido frecuentemente por והנכון. Esto ocurre en varias ocasiones: 1,$22 ; 2,1 ; 2,3 ; 3,65$ y 4,20 , en este caso en el segundo comentario. Por ejemplo, dice en 2,1:

איכה יעיב. יש אומ' יעיב מעב כמ' יחשיך (תהלים קלט,יב) והנכון יגביה עד עב

iAy, cómo ha elevado! (איכה יעיב): Hay quienes opinan que יעיב viene

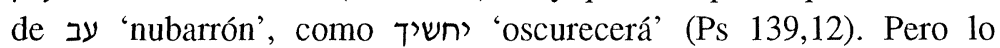

1 Vid. L. PRIJs, Die Grammatikalische Terminologie des Abraham Ibn Ezra (Basel 1950) pág. 44. 
correcto es יגביה עד עב '[el Señor] la ha elevado (a la hija de Sión) hasta las nubes'.

Ibn Ezra rechaza probablemente la relación entre עב y y porque no está de acuerdo con el significado de 'nublarse, oscurecerse'. Según su interpretación, el significado del versículo sería 'el Señor ha elevado a la hija de Sión'. O en 3,65:

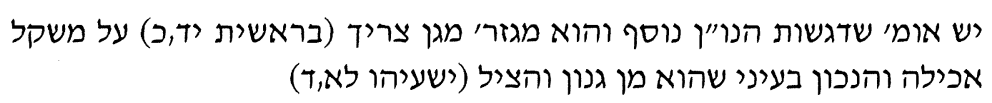

[Protección] [מגנת]: Algunos dicen que el J es prostético y lleva dageš y es derivado de מגן צריך 'entregó a tus enemigos' (Gen 14,20), según el paradigma אכילה 'comida', pero yo creo que lo correcto es que viene de גנון והציל 'amparando y salvando' (Is 31,4).

En este caso, Ibn Ezra deriva la palabra מגנת de la raíz nנן, no de מגן. También Rashi, en su comentario a este pasaje, da como alternativa esta acepción; dice que puede ser un escudo frente al corazón, impidiéndole sufrir ${ }^{2}$. Y R. Isaías de Trani, en su comentario a esta palabra, indica asimismo que es de la raíz נגן, comparándolo con el paradigma de אחיתת דלים (Prov 10,15) ${ }^{3}$.

A veces, en lugar de והנכוב בעיני utiliza, como en 1,4 o והישר לעיני, como en 4,1:

באי מועד. שהיו באים במועדים והטוב בעיני שהוא המקדש ונקרא מועד בעבור היות כל ישראל מעדים שם וכן בקרב מועדיך (תהלים עד,ד)...

Quien venga a la fiesta (באי מועד) son באים במועדים 'los que iban a

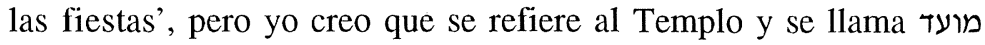
porque todo Israel se reunía allí, y así es בקרב מועדיך 'en medio de tus asambleas' (Ps 74,4)...

2 Vid. Biblia Rabbinica. A Reprint of the 1525 Venice Edition, ed. by J. BEN HAYYIM IBN ADONIYA, 4 vols. (Jerusalem 1972) vol. IV, pág. 296.

3 Vid. R. A. J. WertheImer, Commentary Rabbi Isaiah da Trani the First on Prophets and Hagiographa (Jerusalem 1978) vol. III, pág. רצד. 
איכה יועם. יש אומ' יועם כמ' חשך תרג' כהה הנגע (ויקרא יגוגו) עמיא והישר בעיני שהוא כמו לא עממוהו (יחזקאל לא,ח) ומשקלו לחם יודק (ישעיה הניחו כח,כח)

;Ay, ha oscurecido! (איכה יועם): Hay quienes dicen que ha oscurecido es como משה הנגע 'se ha oscurecido la llaga' (Lev 13,6) se traduce en el Targum por עמיא המח 'oscurecido'. Pero

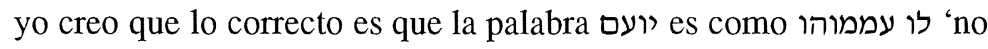
le hacían sombra' (Ez 31,8), según el paradigma de לחם יודק 'el pan será hecho migas' (Is 28,28).

Ibn Ezra está comparando en este caso dos formas correspondientes a dos verbos con raíz reduplicada.

Otra expresión característica de Ibn Ezra es גזר. Muy a menudo, cuando habla de una palabra, utiliza este término para expresar que una palabra deriva de otra o que las dos tienen la misma estructura gramatical. Hay ejemplos en 1,5; 1,8; 3,54 o en 4,1 (ejemplo anterior). En el caso de 3,65 utiliza también la expresión על משקל para indicar un paradigma, como hemos visto en el ejemplo del párrafo anterior. También Rashi utiliza este término en el mismo sentido, como en su comentario a Gen 21,$16 ; 44,15$ o a Is 1,16 .

Para indicar que se omite algo, ya sea partícula, sustantivo o cualquier otro elemento, utiliza el término חס, como aparece en numerosas ocasiones: 1,$1 ; 1,6 ; 1,14 ; 1,21 ; 2,3 ; 2,11 ; 3,1 ; 3,22$ y 4,15 (del segundo comentario). Por ejemplo, en 1,14 dice:

הכשיל. שב אל עול פשעי (איכה א,יד) ויחסר אשר אחר בידי גם אחר קום עמו

או מפניו

Ha hecho tambalear (הכשיל) se refiere a עול פשעי 'ha vigilado sobre mis pecados' (Lam 1,14), pero falta el relativo בידי tras עשר y también tras קום, junto o inmediatamente antes.

\section{CASOS ÚNICOS EN LA BIBLIA}

Tradicionalmente, se denominan casos let los que aparecen una sola vez y en la misma forma en la Biblia. Sin embargo, hay que tener en cuenta el concepto de casos let en la literatura medieval. 
Frecuentemente, no se refiere a un caso único de forma absoluta, como lo entendemos en masora, sino que puede variar dependiendo del análisis gramatical de la palabra. Existen muchos elementos en la palabra por los que puede variar su clasificación: preformativas, aformativas, letras que corresponden a la raíz, raíces débiles, letras laríngeas, etc. ${ }^{4}$

Ibn Ezra utiliza en este comentario distintas expresiones para indicar este fenómeno, aunque en otros escritos utiliza además otras formas. Hay que tener en cuenta que en el libro de Lamentaciones, debido a las características del texto bíblico, los casos let son muy abundantes. En la edición de BHS ${ }^{5}$ se recogen más de cien casos en la masora. Ibn Ezra no refleja todos ellos, sino solamente aquellos en los que existen problemas en la acepción o significado de la palabra, y tampoco en todos los casos.

En Lam 1,14 utiliza אין לו אב ואם para expresar que la palabra נשקד 'ha vigilado' no aparece más que en esta ocasión en la Biblia, aunque para su significado sí que encuentra otros ejemplos similares. La masora coincide en señalarla como única, y también Greenspahn ${ }^{6}$. Con esta expresión, Ibn Ezra se refiere a que la palabra es un let.

מלת נשקד. אין לה אב ואם והטעם כמ' נמשך או נמהר

La palabra ha vigilado (נמשך) es un let y su sentido es como 'arrastrado' (נמשך) o como 'se apresura' (נמהר).

4 Vid. F. Greenspahn, Hapax Legomena in Biblical Hebrew (California 1984). En el capítulo «The Treatment of the Hapax Legomena in the Midle Ages», págs. 71-84, el autor hace una detallada exposición de los tipos de casos únicos que aparecen en los comentarios medievales, así como de la terminología utilizada por los comentaristas para designarlos.

${ }^{5}$ Biblia Hebraica Stuttgartensia. Ediderunt K. Elliger et W. Rudolph, Textum Masoreticum curavit H. P. RÜGER, Masoram elaboravit G. E. WeIL (Stuttgart 1977).

6 Vid. F. Greenspahn, Hapax..., págs. 161-162 y 207. 
En otras ocasiones, y utilizando el sentido metafórico, lo amplía a , הכפישני , incluso a משין לו אח ${ }^{7}$. En Lam 3,16, al referirse a dice Ibn Ezra אין לו איו לו literalmente, 'no tiene hermano'. Esta expresión aparece ya en la masora para indicar que no hay otro caso similar. Ibn Ezra nos muestra así que es palabra let. Esta palabra no aparece como única en la MP de BHS, pero sí en Greenspahn y Mandelkern ${ }^{8}$.

הכפישני אין לו אח והטע' גאלני

Me ha postrado (הכפישני) no tiene semejante y el sentido es 'me ha ensuciado'.

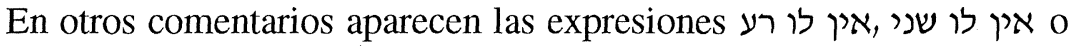

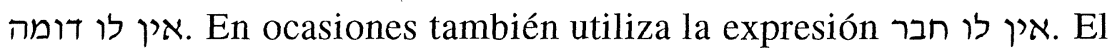
חבר nármino lo toma de la masora, donde aparece frecuentemente con este mismo significado ${ }^{9}$. De hecho, es la forma más usual de indicar pasajes paralelos al enumerar los simanîm en la masora magna.

Otra expresión que utiliza nuestro autor para designar los hápax legomena es לבדו, como ocurre en el caso de Lam 4,8, al referirse a צפד. Compara la palabra con דבק, refiriéndose tanto a su significado como a su forma, y añade que es palabra única ${ }^{10}$ :

צפד. כמ׳ דבק והוא לבדו

Se pega (צפד) es como דבק 'adherirse' y es un caso único.

\footnotetext{
7 Para una mayor información sobre las expresiones de Ibn Ezra, vid. F. GREENSPAHN, «The meaning of 'ein lo domeh», AJSreview (1979) págs. 59-70; ID., "Abraham ibn Ezra and the Origin of some Medieval Grammatical Terms», JQR 76/3 (1986) págs. 217-227.

8 Vid. F. GreEnspahn, Hapax..., págs. $129-130$ y 204 y S. MANDELKERn, Concordantiae Hebraicae atque Chaldaicae, 2 vols. (Graz 1955) vol. I, págs. 597d-598a. La discusión sobre esta palabra es acerca de su significado, aunque todos coinciden en que es un hápax.

9 Vid. I. YeIVIN, Introduction to the Tiberian Masorah (Missoula, Montana 1980) págs. 90 y 93, en este caso para el origen de יחיד.

${ }^{10} \mathrm{La}$ comparación con la raíz דבר השרשים לרבי דויד también aparece en el יוסף קמחי הספרדי (Berlín 1847) pág. 316 (en adelante, Šôrašìm).
} 
También en 4,17 aparece la expresión אין לו משקל referido a la palabra בצפייתנו. En la Biblia es un caso let. Aparece solamente una vez en esa forma, aunque hay más casos de la misma raíz en otras formas ${ }^{11}$.

בצפייתנו. אין לו משקל

En nuestro puesto de vigia (הצפייתנו) no tiene forma [similar].

\section{MORFOLOGÍA}

En varias ocasiones, Ibn Ezra se refiere a la morfología de las palabras. En cuanto a la forma de los sustantivos, Ibn Ezra solamente hace alusión a ellos en dos ocasiones, para indicar que van en estado constructo. En 1,15, dice que, en el conjunto לבתולת בת יהודה, la palabra בתולת va en estado constructo respecto a בת, y especifica que la doncella es Jerusalem, aunque aquí aparezca בת יהודה.

בתולת סמוכה אל בת ובת יהודה כל השבט שהוליד יהודה והבתולה ירושלם

Doncella בתולת) es constructo respecto a בת El conjunto es בת יהודה pero la doncella es Jerusalén.

El otro caso es 3,1, donde afirma que la palabra עני también va en estado constructo, aunque le falta la segunda parte del conjunto, que debería ser הגלות o השבות. Al añadir estas palabras, Ibn Ezra intenta explicar la causa de la aflicción, sugiriendo que, si es Jeremías el que habla, se debe a los últimos años del reino de Judá y posterior destierro de Babilonia. Teniendo en cuenta su propuesta, el versículo debería ser: «Yo soy el hombre que vio la aflicción causada por el cautiverio...»

${ }^{11}$ Vid. S. MAndelkern, Concordantiae Hebraicae, vol. II, pág. 1001d. 
עני סמוך ויחסר מקום השב' או הגלות וראה תחת ראיתי וכן ונשאר אני הגבר

Aflicción (עני) está en estado constructo y falta השבות 'el cautiverio',

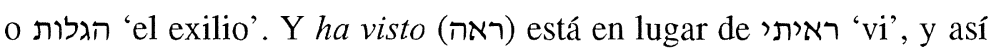
es ונשאר אני הגבר 'y quedé yo solo' (Ez 9,8).

Con respecto al género, distingue entre palabras que pueden ser masculinas y femeninas indistintamente, y otras solamente femeninas o masculinas. Por ejemplo, en 1,3, hablando de יהודה dice que es masculino y femenino, como Israel o Egipto. Se refiere a que los nombres propios, en muchas ocasiones, son considerados de uno $\mathrm{u}$ otro género ${ }^{12}$ :

יהודה. זכר ונקבה כישראל ומצרים ותחזק מצרים (שמות יב,לג)

Judá (יהודה) es masculino y femenino, como Israel o Egipto, ותחזק מצרים 'y apremiaba Egipto’ (Ex 12,33).

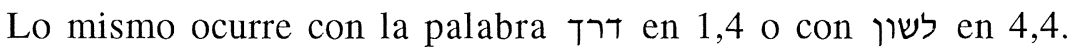
Dice que aparece como masculino y femenino, como בית o como מקום, o simplemente que es masculino y femenino:

\section{נמצא דרך זכר ונקבה כבית ומקום}

Camino (דרך) aparece como masculino y femenino, como בית מקו 'casa' o como מקום 'lugar'.

[לשון] יש להם לש' זכר ונקבה

Lengua (לשון) es masculino y femenino.

Esta idea de Ibn Ezra se recoge también en otras obras ${ }^{13}$ : hay palabras que pueden considerarse dentro de ambos géneros, entre las

12 Vid. Ibn Ezra's Commentary on the Pentateuch, Genesis. Translated and Annotated by H. Norman STRICKMAN \& ArTHur M. Silver (New York 1988) pág. 344. En el com. a Gen 36,40 dice que algunos nombres propios pueden ser utilizados bien como masculinos, bien como femeninos.

${ }^{13}$ Vid. W. BACHER, Abraham ibn Esra als Grammatiker (London 1882; repr. New

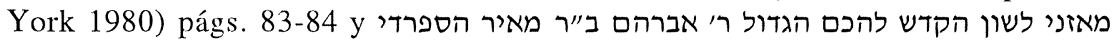
(1791) (en adelante, Mo żnayîm) págs. 33-34. 
que se encuentran estas dos. También otros autores hablan del doble género de algunas palabras. R. David Qimhi, en el Sefer haSôra š̀m ${ }^{14}$, dice, por ejemplo, de מקום que normalmente es masculino, aunque aparece también en femenino; de hecho, en el comentario a Job 6,20 Ibn Ezra señala que מקום es femenino.

En otros casos, simplemente clasifica la palabra como masculino o femenino. Así, en 1,13 afirma que la palabra וירדנה está en masculino refiriéndose a אש. Esta es una de las palabras que puede ser masculino o femenino ${ }^{15}$ :

וירדנה. שב אל האש כי ימצא לש' זכר כמו תאכלהו אש לא נופח (איוב כ,כו)

Y los dominó (וירדנה) se refiere al fuego porque se encuentra en masculino, como תאכלהו אש לא נופח 'la devora un fuego no atizado' (Iob 20,26).

Lo mismo ocurre en 2,4, al tratar la palabra מין, de la que también Qimhi ${ }^{16}$ afirma en este caso que es masculino:

נצב ימינו. בניין נפעל ויש ימין זכר נאדרי בכח (שמות טו,ו)

Ha afirmado su diestra (נצב ימינו) es forma nif'al y מיכון es masculino como נאדרי בכח 'admirable en su fuerza' (Ex 15,6).

Con referencia a palabras femeninas, se cita ראש en 3,5. Sin embargo, esta palabra también está entre las que pueden tener doble género.

(ו.....

...y ראש es femenino...

\footnotetext{
${ }^{14}$ Vid. Šôrašîm, pág. 325.

${ }^{15}$ Vid. Šôrašîm, pág. 28 y Mo żnayîm, pág. 33v.

${ }^{16}$ Vid., Šôrašîm, pág. 141.
} 
También se menciona en el comentario a Lamentaciones el número de los sustantivos. Se indica el plural por medio de letras serviles, que son el mem y el nûn, para el masculino y femenino respectivamente. Esto se cita ya en el Sefer Sahot ${ }^{17}$. Por ejemplo, en Lam 1,4, acerca de la palabra שוממין afirma que la letra nûn es signo de plural y que aparece en lugar de un mem, que sería lo normal.

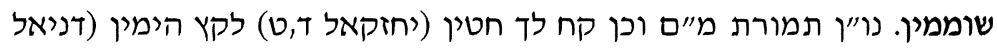

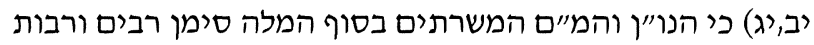

Asoladas (שוממין): el s está en lugar de un מ, y así es קח לק לד חטין 'cógete también trigo' (Ez 4,9), לקץ הימין 'al fin de los días' (Dan 12,13), porque el $\mathrm{s}$ y el $\boldsymbol{b}$ son letras serviles en final de palabra e indican el plural, masculino o femenino.

Este intercambio de las dos letras para indicar el plural lo explica en el Sefer Mo Znayîm $^{18}$ y en otras obras como el Safah Berurah ${ }^{19}$.

El intercambio de las letras אהו"י es frecuentemente tratado por Ibn Ezra ${ }^{20}$, así como por otros comentaristas. Los exegetas medievales utilizan este método de formas distintas. Saadya Gaon y Dunash ben Labrat extienden el intercambio a otras consonantes. Ibn Ezra expone su teoría explícitamente en su comentario a Ecce 9,11 ${ }^{21}$ y también en el Sefer Mo żnayîm habla del intercambio de otras letras como el nûn y mem en la formación del plural ${ }^{22}$, como he mencionado antes. Por ejemplo, en 1,2, acerca de בכו, dice:

\footnotetext{
${ }^{17}$ Vid. C. DEL VALLE, Sefer Sahot de Abraham ibn Ezra (Salamanca 1977) pág. 245.

${ }^{18}$ Vid. Mo źnayîm, pág. 15: «se intercambia el mem con el nûn al final de la palabra en el plural masculino y femenino, como.... שוממין.

${ }^{19}$ Vid. W. BACHER, op. cit., pág. 69.

${ }^{20}$ Vid. Mo żnayîm, pág. 3a, y M. Gómez Aranda, El Comentario de Abraham ibn Ezra al libro del Eclesiastés (Madrid 1994) págs. 147 y 183. Dice en el primer caso de Ecce. que «en la lengua santa las únicas letras que varían, se cambian, se asimilan, se añaden o se omiten son $ו$, , y $\mathrm{K}$, como explicó R. Yehuda bar Daud, el gramático de bendita memoria».

${ }^{21} \mathrm{Vid}$. M. Gómez ARANDA, El Comentario..., pág. 147.

${ }^{22}$ Vid. n. 18
} 
וי"ו בכו תחת ה"א כי אותיות אהו"י מתחלפים כמו הסכלת עשו (בראשית

לא,בח

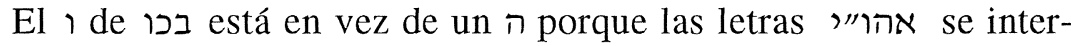
cambian, como en הסכלת עשו 'has obrado neciamente' (Gen 31,28).

En este pasaje de Gen aparece un waw en el lugar de un taw en la palabra עשו. Ibn Ezra explica, en el comentario a este pasaje, que la palabra es un infinitivo constructo (de ahí que debiera terminar en taw), porque el 'ayîn lleva hatef patah ${ }^{23}$. También se habla de intercambio entre 'alef y hê en 3,12:

כמטרא. א׳ במקום ה"א הנקבה והוא מגז' נטר

Como blanco (כמטרא) ${ }^{24}$ : el $\mathrm{N}$ está en el lugar de un ה de femenino y es de la raíz נטר 'vigilar'.

Al referirse a la palabra כמטרא, e indicar que se trata de un femenino, señala que debería terminar en hê. El mismo intercambio de álef y hê se da en 3,33, aunque en este caso se trata del hê de la forma hifull en וויגה:

ויגא. אל"ף תחת ה"א והוא מהבנין הכבד הנוסף כמ’ היצא אחך (בראשית ח,י)

Y aflige (ונוא): el $\mathrm{N}$ está en lugar de un $\mathrm{n}$ y es de la forma hif h̆l, como היצא אחך ‘saca contigo’ (Gen 8,17).

O en 4,2, en המסלאים, el 'alef sustituye al hê ne'elam ${ }^{25}$ :

אל"ף המסולאים. תחת ה"א השורש כי הה"א הנעלם לא ימצא בתוך המלה

El ה de de está en lugar del $\mathrm{N}$ de la raíz, porque el ה es něelam y desaparece en medio de la palabra.

\footnotetext{
${ }^{23}$ El pasaje de 1,2 en el Šôrašîm, pág. 40, se cita con he: בכה.

${ }^{24}$ La masora lo apoya diciendo: $\dot{x}$ ל ל una vez escrito con $\mathcal{X}$.

${ }^{25}$ Vid. L. Prius, Die Grammatikalische..., pág. 100 y C. Del Valle, Sefer Sahot..., págs. 126 ss.
} 
El intercambio de las consonantes puede referirse a dos aspectos: de significado y morfológico. El primero no aparece en el comentario a Lamentaciones, sino solamente el que se refiere al aspecto morfológico de la palabra, como en el caso citado de 1,2. En algún lugar de este comentario amplía su teoría del intercambio de letras a otras consonantes: en 3,8 dice que aparece un sin en el lugar de un samek en la palabra שתם:

שתם. בשי"ן כשמ"ך וכן השירו ולא ממני (הושע ח,ד)

Ha cerrado el paso (שתם): con ש en vez de ס, y así es השירו ולא ממני 'se han nombrado un príncipe sin contar conmigo' (Os 8,4).

Sin embargo, en su comentario a Ecce 10,6 no admite el intercambio entre samek y sîn. Se puede deducir que en el caso del presente comentario, la opinión de Ibn Ezra ha variado y no sorprende que, en el Sefer Mo znayîm admite incluso el intercambio entre mem, nûn y taw, como hemos señalado antes ${ }^{26}$.

La clasificación de consonantes entre serviles ${ }^{27}$ y radicales es común a los comentaristas medievales y refleja la importancia que le dan a la distinción entre letras que pertenecen a la raíz y letras que desempeñan un papel morfológico. Esta distinción también es un asunto que preocupa a nuestro autor en el comentario que aquí tratamos, aunque solamente se refiera al 'alef, bet, mem y nûn. Distingue con frecuencia entre los dos tipos de consonantes, indicando en cada caso por qué hace su afirmación. Por ejemplo, en 1,7 (נמרודיה) y en 2,7 (נאר) indica que el mem y el nûn son de la raíz, para no confundirlas con el mem de la partícula מן o con un nûn indicativo de forma verbal.

\footnotetext{
${ }^{26}$ Vid. nn. 18 y 20.

${ }^{27}$ Las consonantes serviles, en palabras de Ibn Ezra, son כשתיל אב המון (como el disparo del padre de la multitud'). Para la explicación de este significado, vid. M. GómEZ ARANDA, «Grammatical Remarks in The Commentary of Abraham Ibn Ezra on Qohelet», Sefarad 56 (1996) págs 61-82, n. 14; W. BACHER, op. cit., págs. 57-58 y «Les signes mnémoniques des lettres radicales et serviles», REJ 16 (1888) págs. 286-288. Vid. también Mo żnayîm ...págs. 12 ss.
} 
ומרודיה. והמ״ם שורש ומרודיה

Y de vagabundeo (ומרודיה): el מ מ es de la raíz.

נאר. הנו"ן שורש נארת ברית עבדך (תהלים פט,מ) כמ׳ עזב או שנא

He desdeñado (נאר): el s es de la raíz como en נארת ברית עבדך עa "has despreciado la alianza con tu siervo' (Ps 89,40) y como עברד בערת 'abandonar', שנא odiar'.

También en 5,6, dice que el segundo nûn de נתנו es radical, por lo que lleva dage ̌́, o en 3,34 al referirse a לדכא dice que el alef también es radical:

מצרים. דגשות הנו"ן במלת נתנו תחת נו"ן כי זאת הנו"ן השורש...

Egipto: El د [2] de la palabra נתנו lleva dageš porque es un د de la raíz...

לדכא. האלף במלת לדכא שורש

Aplastar (לדכא): el א א de la palabra לדכא es de la raíz.

Específicamente, se designan en este comentario algunas letras como serviles: en 1,17 dice que el bet de בידה es servil (משרתים), refiriéndose a que se trata de la partícula $ב$; y en $1,4{ }^{29}$ dice que el mem y el nûn son serviles porque se usan para indicar plural.

[בידיה] בי"ת בידיה נוסף כמו ותשקמו בדמעות (תהלים פ,ו)

Sus manos: el בידיה de prostético, como ותשקמו בדמעות 'les has dado de beber lágrimas a cántaros' (Ps 80,6).

Para indicar que una letra es prostética, normalmente utiliza el término נוסף, como aparece en numerosas ocasiones en este comentario. Esta palabra la utiliza Ibn Ezra para señalar algo añadido, tan-

\footnotetext{
${ }^{28}$ En BHS es נארתה.

${ }^{29}$ Vid. pág. 378.
} 
to si se trata de una aformativa, preformativa, o cualquier otro tipo de letra que no corresponda a la raíz. Además de letras, también la utiliza para designar palabras ${ }^{30}$. Hay que tener en cuenta que, para Ibn Ezra, el término משרת engloba al término נוסף: todo «servil»es «añadido», pero no al revés.

En este comentario, Ibn Ezra no se refiere con mucha frecuencia a la vocalización de las palabras. Alude específicamente a ello en tres ocasiones: en 1,1, refiriéndose a la palabra למס, dice:

ונפתח למ"ד למס להורות על ה"א הדעת הנעדר ולא נדגש המ״ם להקל על הלשון

El de de de artículo, que ha desaparecido, aunque no se pone dageš en el $מ$ para aligerar la palabra.

Sin embargo, en el TM ese lamed va vocalizado con qames, debido probablemente al sillûq ${ }^{31}$. Otro caso es 1,12 , al referirse a la vocalización de עולל. Dice que se trata de una forma pasiva porque no lleva sêrê, y a continuación da otro ejemplo en el que lo lleva y, por lo tanto, no es forma pasiva.

עולל. נעשה לי והוא מהבנין שלא נקרא שם פועלו בעבור שאינו בקמץ קטן

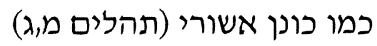

Me hace daño (עולל), me hicieron, es de una forma pasiva porque no lleva sêrê, como כונן אשורי 'se han afirmado mis pasos’ (Ps 40,3).

El tercer caso es el de 3,64, en el que se refiere a la palabra גמול, de la que dice que, tanto en estado absoluto como constructo, lleva šěwa?.

גמול. בסמוך ובמוכרת שוה

La paga (גמול): tanto en estado constructo como en absoluto es con šěwa:.

${ }^{30}$ Vid. L. Priss, Die Grammatikalische.., págs. 58 ss. y Mo żnayt̂m, pág. 22.

${ }^{31}$ También Norzi, tras citar el comentario de Ibn Ezra, dice que debe llevar qames, "según todos los códices correctos y el Mikllol». Vid. Y. S. DE NorZI, ספר מנחתr שי (Viena 1813) en el comentario a Lam 1,1. 
Sí alude Ibn Ezra en más ocasiones al dageš. Normalmente se refiere a él para indicar que falta una consonante, y que el dageš la sustituye. Esta sustitución se produce con frecuencia entre consonantes serviles, como en 3,65 acerca de la palabra מגנת:

יש אומ׳ שדגשות הנו״ן נוסף...

Algunos dicen que el s es prostético y con dageš...

Aunque en esta ocasión Ibn Ezra difiera al opinar que el nûn es de la raíz ${ }^{32}$. O en 5,6 dice:

דגשות הנו"ן במלת נתנו תחת נו"ן כי זאת הנו״ן השורש...

El د [20 [ נתנו lleva dageš porque es un נ de la raíz...

\section{VERBOS}

En sus comentarios, Ibn Ezra marca la diferencia entre verbos transitivos e intransitivos. Tanto en el Mo żnayîm como en el Sefer Sahot ${ }^{33}$, explica que los verbos intransitivos son aquellos en los que la acción del sujeto no afecta a ninguna otra parte de la oración, y los transitivos son aquellos en los que la acción del sujeto «sale» hacia otro elemento de la oración. Sin embargo, unos y otros pueden pasar de una a otra condición al cambiar de conjugación. Utiliza el término פועל עומד para designar los verbos intransitivos ${ }^{34}$, como puede verse en dos ocasiones en el comentario a Lamentaciones (1,16 y 2,3), refiriéndose a ירד y בער.

עיני עיני יורדה מים. עין אנוש דומה לעין המים והעין ותין יורד וכן יזלו מים (ירמיחו ט,ז; תהלים קמז,יח) ושניהם פעלים עומדים

\footnotetext{
32 Vid. pág. 373.

${ }^{33}$ Vid. Mo żnayîm, págs. 43 ss. y C. DEL VALle, Sefer Sahot..., págs. 306-309.

${ }^{34}$ Vid. L. Priss, Die Grammatikalische..., págs. 110-112.
} 
Mis ojos derraman agua (עיני עיני ירדה מים): el ojo humano se parece

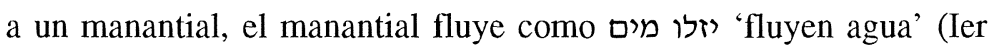
9,17; Ps 147,18). Los dos son verbos intransitivos.

ויבער. פועל עומד...

Ha encendido (ויבער) es verbo intransitivo...

Para designar los verbos transitivos utiliza el término פועל יוצה, aunque no aparece en este comentario ${ }^{35}$.

En un caso se refiere a la naturaleza de la raíz: en 1,20 dice que la palabra חמרמרו tiene sus dos radicales reduplicadas. En este caso, Qimhi coincide con Ibn Ezra, ya que en el Sefer ha-Šrorašm ${ }^{36}$ aparece en la raíz nמר en pilpel, no como raíz cuadrilítera.

חמרמרו. כפול העי"ן והלמ"ד וטע' כמו עכורים וכן פני חמרמרו (איוב טז,טז)

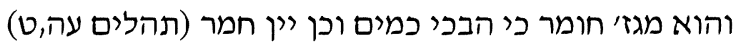

Conmovidas (חמרמרו): se repiten la segunda y tercera radicales y su sentido es como 'turbados', y así es פני חמרמרו 'mi rostro ha enrojecido' (Iob 16,16) y es derivado de חמור, porque el llanto es como agua y así es "ין חמר, 'el vino espumoso' (Ps 75,9).

Sin embargo, al tratar de los verbos, generalmente alude a las distintas formas verbales. Para Ibn Ezra, las conjugaciones varían algo de la clasificación de otros comentaristas, como Dunash o Hayyuj. Considera que hay tres formas principales, qal, pi é $l$ e $h i f^{\prime} \hat{\imath} l$, y en segundo lugar, las demás.

Para referirse al $h i f^{c} \hat{\imath} l^{37}$ utiliza el término כבד נוסף o כבד, como aparece en 1,5:

הוגה. מהבנין הכבד הנוסף מיגון וכן תוגיון נפשי (איוב יט,ב)

\footnotetext{
${ }^{35} \mathrm{Vid}$. nota 34

${ }^{36}$ Vid., Šôră̌î̀m, pág. 109.

${ }^{37}$ Vid. L. PriJs, Die Grammatikalische..., pág. 60, s.v. כסף y y y. GóMEZ ARANDA, El Comentario..., pág. 37, n. 4.
} 
La ha afligido (הוגה) es de la forma hif 'il de יגון y así es תוגיון נפשי 'afligiréis mi alma' (Iob 19,2).

El término כבד también lo usa para el piél. Para el qal utiliza simplemente דרך מדרך o קל. Pero al aludir a las formas pasivas (nif'al o pu'al) dice que no llevan sêerê y que por eso son pasivas. Lo expresa con la fórmula Esto lo vemos en 1,12, al referirse a עולל, como hemos visto antes o en 4,14 al referirse a נגואלו, afirmando que esa palabra encabalga las dos formas pasivas.

נגואלו. מלה מורכבת מבנין נפעל ובניין שלא נקרא שם פועלו

Manchados (נגואלו): palabra que encabalga una forma nif'al y una forma púal.

El hecho de equiparar las dos formas, nif'al con púal, incluso con el hitpaél, aparece también en Rashi ${ }^{39}$. En realidad, esta comparación tiene más que ver con la idea del carácter pasivo que con la propia forma gramatical, lo mismo que ocurre con otros comentaristas.

Para designar el piél utiliza הבנין הכבד. En otras ocasiones simplemente llama a las formas por su nombre; en el hitpa él señala que hay

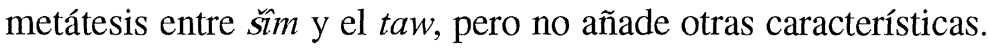

Al hablar de tiempos verbales, en este comentario solamente se señalan en cuatro ocasiones: en dos indica que se trata de un pretérito y en otras dos de un infinitivo. Las dos primeras son 3,11 y 5,18. En los dos casos lo denomina פועל עבר.

יש אומ׳ סורר מגז' סירים וכן הנני שך (הושע ב,ח) והישר בעיני שהוא פיעל

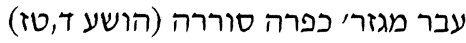

${ }^{38}$ Vid. L. Prus, Die Grammatikalische..., pág. 37. Sin embargo Prijs dice que utiliza esta expresión solamente para referirse al pu'al y al hof'al.

${ }^{39}$ Vid. J. Pereira Mendoza, Rashi as Philologist (Manchester 1940) pág. 23. 
Algunos dicen que espino (סורר) viene de la palabra סירים, y así es הנני שך 'he aquí que voy a vallar' (Os 2,8$)^{40}$, pero yo creo que lo correcto es que es un verbo en pretérito, como en כפרה סוררה 'novilla rebelde' (Os 4,16).

על הר. פועל עבר כמ' כאשר אהב (בראשית כז,ט,יד) הלכו...

Sobre la montaña: [con el] verbo en pretérito como כאשר אהב como gustaba' (Gen 27, 9,14)...

Y cuando habla de infinitivo en 3,19 y 5,13, dice שם הפועל

זכר עניי שם הפועל כזכור בניהם (ירמיהו יז,ב)...

El recordar mi cuita (זכר עני) es un infinitivo, como בזכור בניהם 'como el recordar de sus hijos' (Ier 17,2)...

נשאו. בחורינו לטחון ויהי טחון שם הפועל כמ' נלאיתי נשוא (ישעיהו א,יד)...

Llevaron: los jóvenes han llevado la muela. טחון es un infinitivo, como נלאיתי נשוא 'estoy cansado de soportar' (Is 1,14)...

\section{PARTí́CULAS}

En las cuatro ocasiones en que Ibn Ezra hace referencia a las partículas en este comentario, es para expresar que falta la partícula en el régimen de un verbo o en una oración de relativo. Esto ocurre, por ejemplo, en 1,6 o en 1,14. En el primer caso, se refiere a la falta de כאילים tras, y compara el caso con el de Is 11,9, que también se trata, como en los dos casos anteriores, de una oración asindética, en las que puede faltar el relativo ${ }^{42}$ :

\footnotetext{
${ }^{40}$ Se refiere a la palabra בסירים que aparece en el versículo más adelante.

${ }^{41}$ Vid. L. Priss, Die Grammatikalische..., págs. 110 y 137.

${ }^{42}$ Vid. T. Muraoka y Z. Shavitsky, «AIE's Biblical Hebrew Lexikon. The Five Megilloth», Abr Nahrain 26 (1988) pág. 73.
} 
Sef 63:2 (2003) OBSERVACIONES GRAMATICALES EN EL COMENTARIO DE...

יחסר מקום אשר אחר כאיילים וכן כמים לים מכסים (ישעיהו יא,ט)

Falta poner מאילים detrás, como en כמים לים מכסים como las aguas cubren el mar' (Is 11,9).

הכשיל. שב אל עול פשעי (איכה א,יד) ויחסר אשר אחר בידי גם אחר קום עמו

או מפניו

Ha hecho tambalear (הכשיל) se refiere a עול פשעי 'ha vigilado sobre

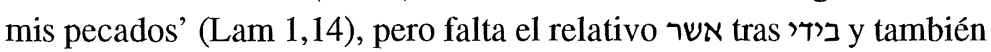
tras קום, junto o inmediatamente antes.

En el caso del régimen verbal, en 1,5 señala que falta la partícula ב בי en la palabra 'cautiverio', y en 1,21 falta תבאת ב ante, aunque en este caso señala que también es correcto tal y como está en el texto:

הלכו שבי. בחסרון בי"ת כמו הנמצא בית ה' (מלכ׳ יב,יא)

Han marchado en cautiverio (הלכו שבי): falta un בנמצא como en 'el que se encuentra en la casa de Dios' (2 Reg 12,11).

הבאת יום קראת. תחסר מלת לו טרם הבאת כאילו הוא מתאוה ויתכן להיות

כמשמעו

Haz llegar el anunciado dia (הבאת יום קראצ): falta la palabra לו המת ante הבאת, es como si lo pidiera, pero también puede ser como está en el texto.

También se señala la falta de la partícula ל en 1,1, al decir que la palabra בדד puede ir con lamed o sin él:

בדד שם נופל על זכר ועל נקבה עם למ״ד ובחסרות וכן מלת בטה (משלי יב,יח)

Solitaria (בדד) es un nombre que puede unirse a masculino o a femenino, con ל ב o sin él, y así también es la palabra בטח (Prov. 12,18).

Se refiere a que se trata de un adverbio, que puede aparecer en la forma לבדד o בדד. También en el comentario a Ps 4,9 dice Ibn Ezra: 
《la palabra לבטח es con lamed o sin él, y así es la palabra que también puede ser nבט».

\section{CONCLUSIONES}

Hemos visto, a lo largo de este análisis, que Ibn Ezra considera las reglas gramaticales de la lengua hebrea como uno de los elementos primordiales a la hora de interpretar el texto bíblico. Por ello, intenta ser lo más cuidadoso posible y seguir muy de cerca esas reglas cuando quiere dar su opinión o explicar un pasaje de la Biblia.

Aunque el comentario de Lamentaciones no es muy extenso, se observa que Ibn Ezra siempre ilustra sus opiniones con otros pasajes, comparando unos con otros, para poder atestiguar sus normas gramaticales. En el comentario a Lamentaciones, estas normas se ven influenciadas por las de otros comentaristas anteriores, y pueden considerarse como un resumen de otras más extensas escritas anteriormente. Algunas de las teorías más significativas se omiten aquí, dándose por sabidas, probablemente debido a que ya estaban expuestas en otros comentarios. 


\section{RESUMEN}

Uno de los principales objetivos de Abraham Ibn Ezra en sus comentarios bíblicos es el estudio de la gramática hebrea y sus características. En sus comentarios podemos encontrar expuestas muchas de sus teorías acerca de este tema. A menudo hace observaciones acerca de las consonantes hebreas, de su vocalización, morfología, de verbos y nombres, etc., utilizando expresiones típicas de su estilo. En el presente trabajo se analizan los aspectos gramaticales del comentario de Ibn Ezra al libro de las Lamentaciones, intentando relacionar sus teorías con las de otros comentaristas medievales.

Palabras Clave: Comentarios bíblicos, hebreo, Lamentaciones, Ibn Ezra.

\section{SUMMARY}

One of the main concerns of the biblical commentaries of Abraham Ibn Ezra is the study of the Hebrew grammar and its characteristics. There we can find indeed many of the theories he had on the subject. Ibn Ezra includes remarks about the consonants, punctuation, morphology of verbs and nouns, etc., using several expressions which are characteristic of his own style. The present paper aims at analyzing the grammatical aspects of the commentary of Ibn Ezra on Lamentations, and at the same time comparing his theories with those of other Medieval commentators.

KEwords: Biblical commentaries, Hebrew, Lamentations, Ibn Ezra. 